\title{
A religião através do estilo: a figuração do espiritismo nas telenovelas brasileiras
}

\section{Simone Maria Rocha e Marcos Meigre}

\section{Resumo}

Analisamos a figuração do espiritismo em três telenovelas da TV Globo: A Viagem, Alma Gêmea e Além do Tempo, atentando-nos a eventos narrativos nos quais ocorre a morte de personagens principais. 0 investimento neste recuo histórico permite captar alterações estilísticas no modo de figurar preceitos básicos da religião, como a existência da alma, reencarnação e atuação dos espíritos sobre a materialidade terrestre. Nota-se maior teor didático nas duas primeiras obras, não reforçado na última produção. Sustentados pelos Estudos Visuais e a metodologia de Jeremy Butler sobre estilo televisivo, apontamos avanços estilísticos associados a reconfigurações socioculturais (televisualidade).

\section{Palavras-Chave}

Televisualidade. Evento narrativo. Espiritismo.

Simone Maria Rocha | rochasimonemaria@gmail.com Doutora em Comunicação e Cultura pela Universidade Federal do Rio de Janeiro - UFRJ, Brasil. Pós-doutora em Comunicação pela Universidade Federal de Minas Gerais - UFMG, Brasil. Professora do Programa de Pós-Graduação em Comunicação da UFMG. Coordenadora do Grupo de Pesquisa Comunicação e Cultura em Televisualidades - COMCULT.

Marcos Meigre I marcosmeigre@hotmail.com Mestre em Comunicação pela Universidade Federal de Minas Gerais - UFMG, Brasil. Membro do Grupo de Pesquisa Comunicação e Cultura em Televisualidades - COMCULT.

\section{As imbricações entre televisão e cultura}

Nas últimas seis décadas, a telenovela brasileira passou por ressignificações importantes que vão de alterações em termos de formato, até mesmo a mudanças no tocante aos modos de consumo. Estas transformações, de ordem material e imaterial, são reflexo direto das dinâmicas socioculturais vividas por nossa sociedade, que reajustam o lugar e as funções do melodrama no contexto brasileiro. De um surgimento atrelado às origens radiofônicas e teatrais até as mais recentes produções embasadas na inovação de formatos, a telenovela se adapta às demandas sociais e acompanha as alterações históricas, políticas e culturais do país. Lopes (2004) assegura o potencial da telenovela brasileira não apenas nos lares do país, mas também a boa acolhida das produções em outras nações. Esta investida transcultural, porém, não fez com que 0 principal produto ficcional latino-americano perdesse sua identidade.

A produção da telenovela representou, por sua vez, uma certa apropriação do gênero em cada país: sua nacionalização. Pois bem, se é certo 
que 0 gênero telenovela implica rígidos estereótipos em seu esquema dramático e fortes condicionantes em sua gramática visual - reforçados pela lógica estandardizadora do mercado televisivo mundial -, também o é que cada país fez da telenovela um particular lugar de cruzamentos entre a televisão e outros campos culturais, como a literatura, o cinema, o teatro. (MARTíN-BARBER0, REY, 2001, p. 118, grifos dos autores)

Mittell (2010) afirma que a televisão deve ser entendida em sua complexidade compósita, estruturada num panorama com seis facetas interligadas diretamente entre si. Para este autor, a TV atua como representação cultural; possui uma forma textual própria; é uma instituição democrática, ao passo que também se configura como indústria comercial; é ainda meio tecnológico e prática cotidiana. Entendemos que analisar televisão é uma tarefa que envolve esforços articuladores, evitando fragmentações que segreguem o meio e seu potencial como um todo.

Nosso movimento de pesquisa parte do meio televisivo, entendido como prática cultural e, após deixarmos as imagens se manifestarem, buscamos nos processos sociais os atravessamentos capazes de sustentar o emprego dos recursos estilísticos na materialidade em questão. Dito de outra forma: consumimos as imagens de modo a reconhecer os elementos externos a ela que lhe jogam importante papel em sua conformação, tais como a História, a política, a economia, as práticas religiosas, etc. A televisão, enquanto meio cultural responsável por reverberar as práticas sociais, torna evidentes as mudanças processadas no âmbito da cultura. Em nossa realidade latina, é através da televisão que a maior parcela populacional acessa os costumes, apreende diretrizes cidadãs, posiciona-se em relação a demandas políticas e sociais, dentre outras questões. É, em síntese, pela TV que a modernidade nos é dada a conhecer, inserindo-nos numa gramática visual.

[...] as maiorias da América Latina estão se incorporando à, e se apropriando da, modernidade sem deixar sua cultura oral, isto é, não por meio do livro, senão a partir dos gêneros e das narrativas, das linguagens e dos saberes, da indústria e da experiência audiovisual. (MARTíN-BARBER0, REY, 2001, p. 47)

As práticas religiosas, pela força adquirida no cenário sociocultural brasileiro, são uma das matrizes fundamentais na conformação dos enredos audiovisuais. Nesse sentido, acompanhando a evolução da doutrina espírita na composição da história nacional, este artigo pretende investigar de que maneira os preceitos espíritas são figurados em três telenovelas brasileiras, veiculadas pela TV Globo. Atentaremo-nos para três telenovelas produzidas e exibidas pela TV Globo: A Viagem (1994, Ivani Ribeiro), Alma Gêmea (2005/2006, Walcyr Carrasco) e Além do Tempo (2015/2016, Elizabeth Jhin). Notamos a proeminência de preceitos espíritas na composição das referidas obras, de modo que temáticas como reencarnação e influências espirituais, por exemplo, foram abordadas ao longo de toda a exibição destas narrativas. 
A escolha das obras levou em consideração dois aspectos principais: o primeiro deles se refere ao interesse em coletar telenovelas veiculadas nas últimas três décadas, de modo a captar possíveis reconfigurações na maneira de figurar a religiosidade; e, em segundo lugar, buscamos produções de autorias distintas, a fim de demonstrar que 0 debate envolvendo espiritismo se pulverizou pela escrita de diversos novelistas e não se tornou marca exclusiva de um único nome.

Neste artigo, discorreremos sobre a figuração do espiritismo em três produções da teledramaturgia brasileira a fim de captar possíveis encaminhamentos socioculturais relacionados ao processo de difusão, aceitação e ampliação da referida doutrina religiosa no Brasil. De acordo com o codificador do espiritismo, a religião se fundamenta em crenças como imortalidade da alma, reencarnação e comunicabilidade dos espíritos (KARDEC, 2007a). Para este texto, seguimos o percurso da visualidade e 0 estilo televisivo como norteadores quanto ao método e metodologia, respectivamente.

\section{Visualidade e estilo: investimentos para mirar a televisão}

Para estudar a televisualidade de nosso objeto, convocamos autores que nos convidam a proceder sob um novo método investigativo, assentando-nos no que vem sendo chamado de Estudos Visuais. Os Estudos Visuais são entendidos como o campo de investigação, enquanto a Cultura Visual, à concepção de Mitchell (2005), seria 0 objeto de estudo. Neste campo, Mitchell sugere um esforço de descontaminação do olhar para que as imagens possam ser entendidas quase como seres vivos, capazes de nos dizer algo e interessadas em serem "ouvidas". Livramo-nas, assim, das amarras dos pré-julgamentos, muitas vezes estereotípicos e matizados por padronizações coletivas.

Não se trata mais de um estilo de pesquisa no campo da história das imagens, e sim de pensar nas formas pelas quais as imagens, através de interesses específicos, são produzidas, circulam e são consumidas, com o objetivo de reforçar ou resistir a articulações com os mais variados objetivos políticos, econômicos, culturais, etc. [...] Os Estudos Visuais questionam como e por que as práticas de ver (visualidade e visibilidade) têm transformado nosso universo de compreensão simbólica, nossas práticas de olhar, nossas maneiras de ver e fazer. (PEGORARO, 2011, p. 45)

Procede-se a um giro pictorial, sugerido por Mitchell (2009), de modo a compreender a dimensão social do visual e entender a imagem como uma realização da sociedade, intricada num processo frequente de se dar a ver para os sujeitos. Esta visualidade, por sua vez, encontra condicionantes - tais como o suporte técnico e o modo do contemplar, por exemplo - mas está diretamente atrelada aos aparatos, às instituições (instâncias sociais que produzem as imagens e as fazem circular), aos corpos (sujeitos que assumem 0 lugar de observador e completam 0 circuito visual - é preciso que tenha alguém para "ver") e, por fim, a figuralidade, que diz respeito à capacidade da imagem de representar 0 mundo, 
de figurá-lo. A experiência visual como um todo é reveladora dos modos de interação em sociedade, podendo inclusive nos dizer sobre a maneira como homens e mulheres assumem papéis e se projetam no ambiente social, evidenciando a construção das relações sociais em jogo.

Interessa-nos um investimento televisual e cultural, de modo a entender o meio em sua poética. A nosso ver, o alinhamento entre a materialidade constituinte dos objetos midiáticos e as determinações culturais auxiliam nos estudos das formas textuais - por vezes negligenciadas nas pesquisas do campo, como afirma Mittell (2010). Uma pesquisa interessada em contemplar a complexidade do meio não pode minimizar a importância de uma das facetas.

Somente assim se torna viável um entendimento de toda a televisualidade constituinte do processo comunicativo.

Televisualidade se refere aos modos como o texto televisivo evidencia questões da cultura (ROCHA; ALVES, 2014). Procede-se, neste trabalho, a uma análise televisual e uma análise cultural: 0 primeiro passo é deixar as pictures, como nomeia Mitchell (2005), interpelarem-nos, entender o que elas têm a dizer, sem aprisioná-las em significados dados de antemão; em segundo lugar, buscamos reconhecer e validar na dimensão social as figurações evidenciadas pela materialidade.
Em síntese, significa partir do audiovisual e ir à cultura para ler nas matrizes culturais os sentidos investidos no produto.

A potencialidade destes estudos não está em "preparar os exercícios praticantes de seus sacerdócios" (BREA, 2009, p. 05), ou seja, não buscam sistematizar modos ideais de ver e interpretar imagens, mas fomentam 0 crescimento do campo a partir de ponderações críticas sobre as práticas sociais. Não se trata de enquadrar o espectador em regimes de visibilidade, mas permitir reflexões acerca do mundo imagético ao seu redor. Trata-se, portanto, de um novo modo de proceder diante do audiovisual, evocando um método que confira às imagens 0 direito de se darem a ver.

Ao assumirmos um novo método, somos conduzidos à busca de uma nova metodologia capaz de articular este jeito de olhar. Em nosso trabalho, adotamos a concepção de Butler (2010) quanto ao estilo televisivo, entendendo-o como todo padrão técnico de imagem-som que exerça alguma função no texto de TV ${ }^{1}$. 0 estudo do estilo "permite-nos entender tanto o programa isoladamente quanto tecer especulações sobre a cultura na qual ele está inserido" (ROCHA, 2014, p. 1089). Esta perspectiva de trabalho faz emergir a poética televisual, pois nos leva a compreender as especificidades e demandas do meio a partir 
de seus aspectos materiais e imateriais. É o que temos denominado de televisualidade, referindose aos elementos intrínsecos à TV, bem como aos componentes socioculturais que sobre ela influem.

Os componentes estilísticos são cruciais para a conformação da mensagem audiovisual, dotados de significações embasadas na cultura, pois “[...] a televisão apóia-se no estilo - cenário, iluminação, videografia, edição e assim por diante - para definir o tom/atmosfera, para atrair os telespectadores, para construir significados e narrativas" (ROCHA, 2014, p. 1089). Por isso, não deve ser negligenciado, já que agrega significações à mensagem.

0 estilo é a textura tangível do filme, a superfície perceptual com a qual nos deparamos ao escutar e olhar: é a porta de entrada para penetrarmos e nos movermos na trama, no tema, no sentimento - e tudo mais que é importante para nós (BORDWELL, 2008, pp.57-8).

Butler (2010) propõe o estudo do estilo televisivo em quatro dimensões: descritiva, analítica/ funcional, histórica e avaliativa ${ }^{2}$. Descrever, segundo o autor, é fragmentar a materialidade audiovisual em sintagma por sintagma, valendose da mesma atenção e apuro que diretores, cinegrafistas, fotógrafos e outros profissionais tiveram ao elaborar a peça. Este procedimento remete a uma "engenharia invertida" e é o passo básico dos estudos estilísticos. A dimensão analítica/formal diz respeito aos propósitos exercidos pelo estilo, podendo denotar, expressar, simbolizar, decorar, persuadir, saudar/interpelar, diferenciar e significar imediatismo. 0 estilo somente é capaz de exercer funções por buscar sustentação na conformação cultural da sociedade. Por fim, para dimensionar a evolução histórica do estilo, é preciso retroceder em programas de um mesmo gênero a fim de identificar as transformações ocorridas.

Para adentrar a um objeto midiático do porte das telenovelas, primeiramente se faz necessário delimitar o corpus empírico. Em obras ficcionais, os eventos narrativos (ROCHA; ALVES; OLIVEIRA, 2013) vêm sendo adotados como um viável aporte de delimitação, pois tais eventos se caracterizam como micro-histórias entrelaçadas ao enredo principal, compostas por início, meio e fim, podendo se estender durante alguns capítulos. Assassinatos, crimes, casamentos são exemplos de eventos narrativos. Neste trabalho, coletamos a parte final do evento narrativo referente à morte dos personagens principais de cada telenovela, bem como uma sequência do evento narrativo imediatamente subsequente, trazendo a nova aparição dos personagens após o falecimento. Nossas análises foram operacionalizadas atentando-nos para a figuração da morte das personagens principais; a figuração dos espíritos (alma); e a figuração da reencarnação. A 
organização das análises privilegia a divisão por telenovela e não por operador analítico a fim de evidenciar as particularidades das produções ficcionais e o que cada uma delas pode revelar quanto aos modos de difusão e apreensão do espiritismo na televisualidade brasileira dos últimos vinte anos. Para melhor apreensão dos sentidos investidos nas obras, seguimos adiante com pontuações relevantes sobre o histórico do espiritismo que nortearão o campo de análises.

\section{Breves ponderações quanto ao espiritismo e sua inserção na cultura brasileira}

0 espiritismo é considerado uma das principais religiões dentro do cenário cultural brasileiro e, segundo dados do $\mathrm{IBGE}^{3}$, a última década presenciou uma ascensão considerável no número de adeptos declaradamente seguidores da doutrina codificada por Allan Kardec. Em 2000, o censo apontava 2,3 milhões de espíritas no país, número que saltou para 3,8 milhões na mensuração de 2010. Além de fatores quantitativos, o Instituto também identificou outras tendências relacionadas à referida matriz religiosa em questão. De acordo com o IBGE, os seguidores do espiritismo apresentam melhores níveis educacionais e salariais se comparados aos membros de outras religiões. De fato, o espiritismo está atrelado à cultura elitista, definido como "uma religião letrada, no sentido de seu enraizamento em temas e emblemas que caracterizam a modernidade Ocidental desde 0 século XIX, como o racionalismo iluminista, o cientificismo e o gênero romance" (LEWGOY, 2000, p.12).

0 espiritismo foi codificado pelo pedagogo francês Hippolyte Léon-Denizard Rivail (Allan Kardec), que se interessou pelas chamadas "mesas girantes", por volta de 1848, ocorridas nos salóes parisienses. A elite se reunia para admirar as mesas que levitavam e obedeciam aos mandos dos presentes. À mesma época, nos Estados Unidos, o caso das irmãs Margaret e Katie Fox repercutiu por elas se comunicarem com espíritos (SANTOS, 1997). Após examinar ocorrências deste tipo em várias partes do mundo, Kardec codificou a referida doutrina e definiu que:

0 Espiritismo é, pois, a doutrina fundada sobre a existência, as manifestações e os ensinamentos dos Espíritos. Essa doutrina se acha exposta, de maneira completa, em 0 Livro dos Espíritos para a parte filosófica, em 0 Livro dos Médiuns para a parte prática e experimental, e em 0 EvangeIho Segundo o Espiritismo para a parte moral (KARDEC, 2007b, p. 186)

A citação sinaliza para uma das marcas do espiritismo: seu aspecto tríplice, intitulandose ciência, filosofia e religião. Na Europa, 0 surgimento atrelado a elites intelectuais permitiu o desenvolvimento das dimensões científica e filosófica, enquanto a vertente religiosa se consolidou em terras brasileiras. A chegada do 
espiritismo ao Brasil se deve à circulação da burguesia europeia pelo país e aos contatos estabelecidos entre letrados nacionais e internacionais, que fizeram o movimento irromper no Rio de Janeiro e, a partir de 1865, assumir maiores proporções na Bahia (MACHADO, 1996).

Desde então, o Brasil se consagrou como ambiente profícuo para o espiritismo, a ponto de ser hoje o principal país espírita do mundo, com maior visibilidade que a França. Aqui, condições sociais favoreceram o desenvolvimento da dimensão religiosa - e não apenas os aspectos filosóficos e científicos, como na Europa. Enfrentados os entraves iniciais, quando, por exemplo, a legislação brasileira (por meio do Código Penal de 1890) considerava criminosa a prática espírita e condenava seus adeptos, com reclusões de até seis meses ou pagamento de 500 mil réis (ARRIBAS, 2010), o espiritismo sedimentou um lugar de legitimidade perante a sociedade brasileira.

Esta legitimidade é reflexo da relação dialógica da doutrina com matrizes religiosas já instauradas no país: a prática da caridade aproximou-se dos preceitos católicos; as sessões mediúnicas encontraram amparo nas crenças afro-brasileiras; a visão cosmológica apontando para a existência de um mundo invisível a nos influenciar agradava às crendices populares sustentadas na ideia de almas penadas e encostos; e seu viés racionalista, cientificista e filosófico atraía os olhares das camadas intelectualizadas (PAVAM, 2003). Tal diversidade gerou duas óticas de estudos do espiritismo no país: uma aponta-o como deformação das orientações estabelecidas na França (MACHADO, 1996; AUBRÉE;

LAPLANTINE, 2009), enquanto a outra visualiza a prática no Brasil como reconstrução original adaptada ao país (DAMAZIO, 1994; GIUMBELLI, 1997), modelando um "espiritismo à brasileira" (STOLL, 1999, p. 282).

Em termos sintéticos, a doutrina espírita defende a imortalidade da alma, reencarnação, possibilidade de comunicação entre vivos e mortos (através de médiuns), a importância da caridade, a pluralidade de mundos e supremacia de Deus (KARDEC, 2007a). No Brasil, a visibilidade de lideranças espíritas ajudou a conformar preceitos acerca da religião através de nomes como Bezerra de Menezes (primeiro presidente da Federação Espírita Brasileira) e Divaldo Franco (principal médium espírita da atualidade). Mas Francisco Cândido Xavier (Chico Xavier) e suas ações mediúnicas e psicográficas ${ }^{4}$ foram as que mais contribuíram para ampliar o espiritismo brasileiro.

Estas ponderações confirmam a importância sociocultural da doutrina para o Brasil, onde a religião encontrou solo forte, afinal: 
"é impossivel entender os caminhos pelos quais passou e passa a religiosidade no Brasil sem considerar a referência que representam o espiritismo e os cultos afros [...] mesmo sem nunca ter chegado perto de se tornar maioria, são muito mais do que minorias" (GIUMBELLI, 1997, p. 237).

Com base nas constatações elencadas neste tópico, torna-se possível prosseguir às análises das materialidades coletadas, iniciando-se pela telenovela $A$ Viagem.

\section{A Viagem e o didatismo espírita na TV}

A Viagem foi exibida em 1994, no horário das 19 horas pela TV Globo, e trata-se de um remake de obra homônima também de autoria de Ivani Ribeiro, produzido e exibido pela TV Tupi, em 1975. 0 sucesso do remake fez com que a telenovela ganhasse duas reprises no canal carioca, em 1997 e também em 2006. Além disso, recentemente o canal Viva reapresentou $A$ Viagem entre 2014 e 2015, sendo a reprise de maior sucesso da história do canal na faixa em que fora exibida ${ }^{5}$.

0 evento narrativo que interessa a este trabalho diz respeito à morte de Alexandre, após cometer suicídio na penitenciária onde se encontrava recluso. Alexandre, condenado por assassinato, decide acabar com a própria vida ao invés de suportar a pena. 0 corpus de análise se refere especificamente ao momento em que 0 personagem, já caído ao chão da cela após ter ingerido grande quantidade de medicamentos, é encontrado morto. Toma-se também para composição do corpus a aparição do espírito de Alexandre no próprio funeral, sendo este trecho pertencente a outro evento narrativo.

A sequência considerada tem início com uma tomada de câmera baixa, com Alexandre deitado (figuras 1-2). Há pessoas se aproximando da cela e um corte mostra sujeitos enquadrados em plano médio lateral, abrindo a cela sob gritos de "Ajuda ele, doutor, ajuda ele!" proferidos por detentos. Já dentro do recinto, Alexandre é revirado pelo médico. Captamos o rosto através de close up: olhos abertos, sem reflexo, pele avermelhada e secreção na boca ele está morto! 0 médico, em plano médio, exclama em tom pessimista: "Essa não!".

Figuras 1-2: A morte de Alexandre (A Viagem)

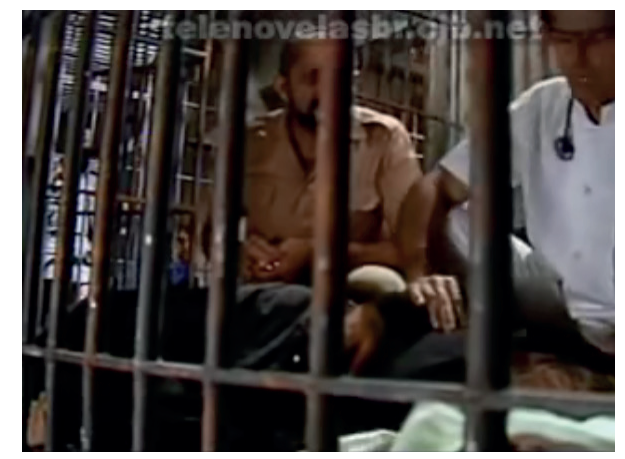




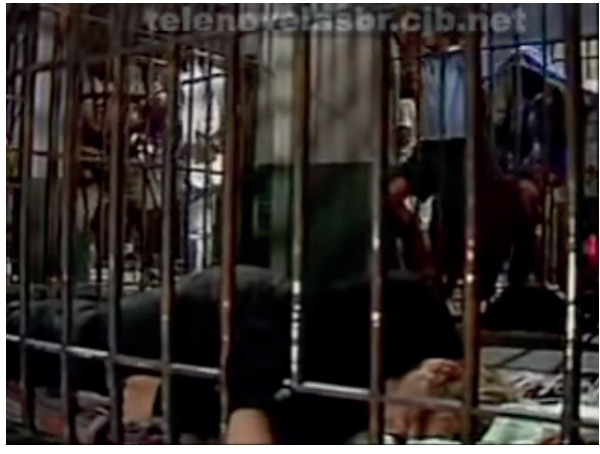

Fonte: Youtube

Deparamo-nos com close up do rosto de Alexandre, sem vida, desfigurando-se até dar a ver nuvens cinzentas iluminadas por raios de sol (figuras 3-5). A transformação do rosto de Alexandre em nuvens simboliza o descolamento de seu espírito do corpo e a subsequente condução para o plano espiritual. Apesar de tons amarelados remetendo ao sol, são nítidas as nuvens escuras, numa conotação ao próprio estado evolutivo da personagem recém-falecida: Alexandre carregava consigo uma áurea de tormentas e instabilidade.

A trilha musical reverbera o tom dramático, pois se trata de uma melodia instrumental funesta. Encerrando, há uma gaivota sobrevoando o mar, diante de um horizonte ensolarado, entremeado por nuvens escuras. 0 canto da gaivota compõe 0 tom fúnebre e soa tal qual sino ao anunciar uma morte, através de badalos. A gaivota segue voo e a perdemos de vista quando se coloca diante da projeção do sol, imponente e a dominar parte do quadro. É como se Alexandre sumisse de nosso campo de visão para adentrar numa dimensão existencial impossível de ser captada por olhos humanos.

\section{Figuras 3-5: Alexandre morto em A Viagem}
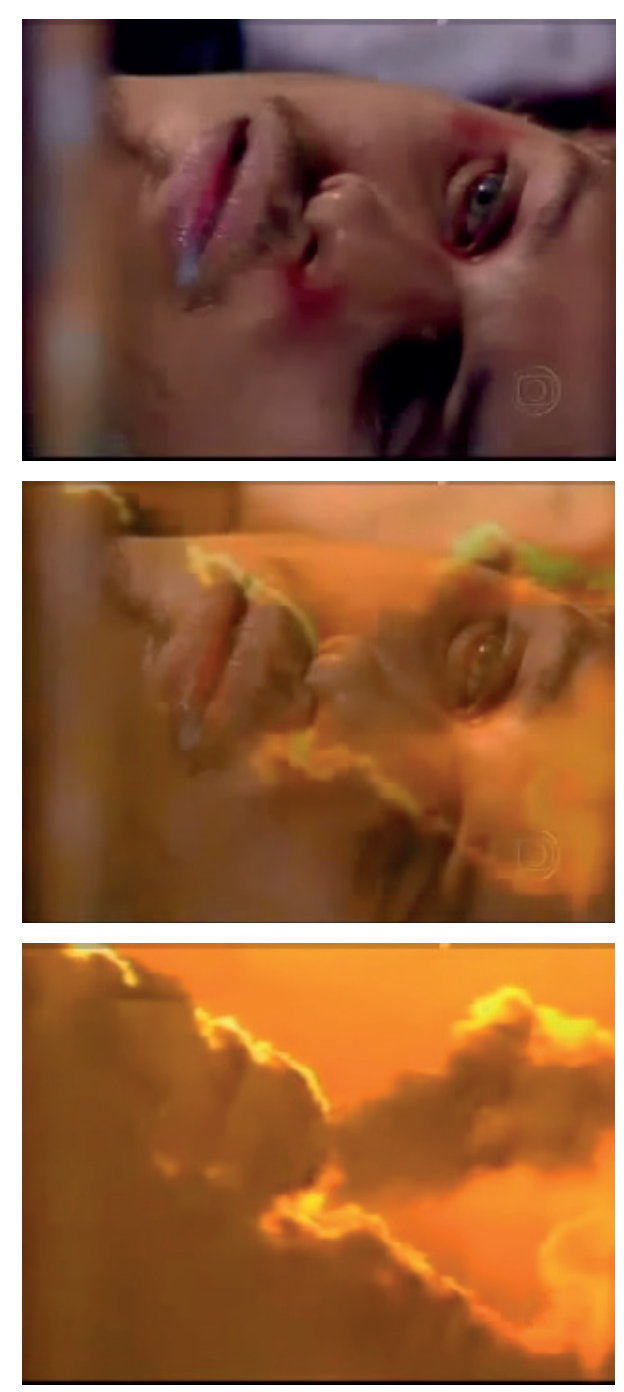

Fonte: Youtube

Em todas as ocorrências nas quais Alexandre surge, a aparição se deu por meio de composição cênica capaz de refletir não só a condição física do personagem (um prisioneiro) como também simbolizou a própria existência conturbada que o marcou: enquadrado por detrás das grades, não há uma única captação de imagem dentro da cela e toda a sequência é marcada por gritos dos presos, com frases indefinidas, misturadas 
entre si, reforçando o conturbado estado de aprisionamento no qual vivera Alexandre - prisioneiro de suas próprias ações, refém das consequências. No velório, inicia-se com movimento de câmera lateral que circunda 0 ambiente e capta os presentes de pé, vestidos de preto e com semblantes de pesar. Há close up de alguns personagens (irmão e cunhada de Alexandre), seguidos por plano aberto evidenciando a mãe e as irmãs, além de outros sujeitos no local. Em plano médio, um senhor com a Bíblia Sagrada lê 0 trecho "0 Senhor é o meu Pastor e nada me faltará".

Enquanto o homem fala, o espírito de Alexandre surge, sob efeito sonoro breve como sopro de vento. Uma áurea branca no exato formato do personagem aparece num plano médio e, encerrado o efeito sonoro, Alexandre assume sua forma corpórea e começa a caminhar pelo espaço. Passamos a enxergar pelos olhos de Alexandre, através de uma câmera subjetiva - que se intercala com uma câmera responsável por captar 0 espírito em plano médio e dar a ver seu rosto. Ele caminha em direção à irmã Diná, na intenção de abraçá-la, mas não consegue.

Figuras 6-8: Alexandre em espírito surge no próprio velório

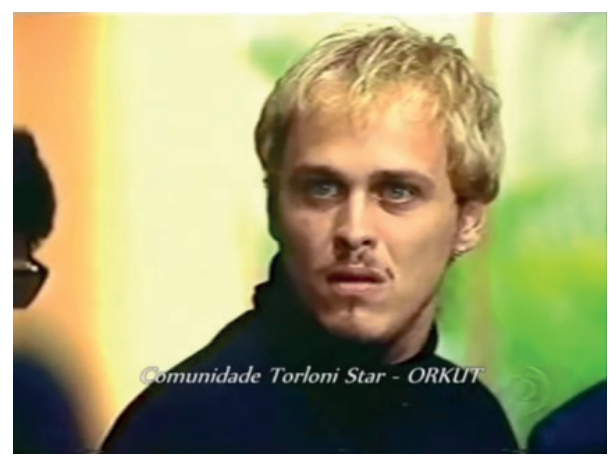

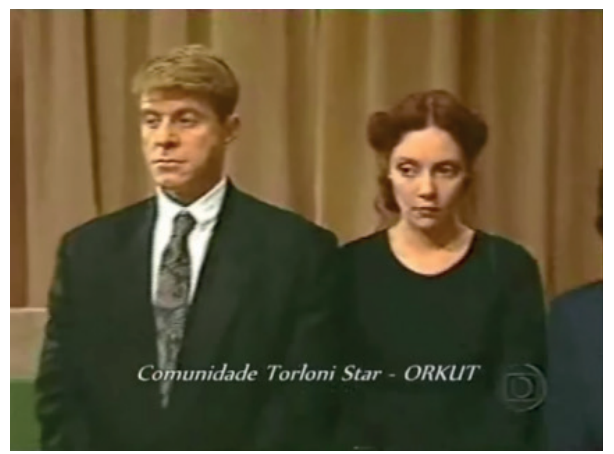

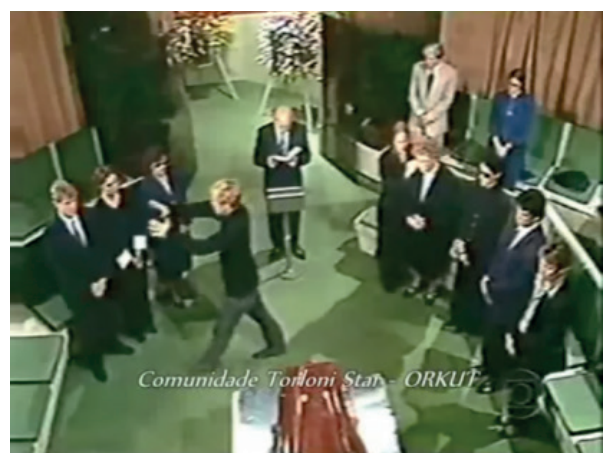

Fonte: Youtube

Alexandre rodeia 0 espaço com os olhos e vemos este movimento brusco. A câmera sai de Diná e, numa rápida guinada para a esquerda, fixa em Raul (irmão). Em seguida, o espírito olha para o caixão, avista 0 cunhado e tenta agredi-lo, em vão. 0 cunhado olha para o lado e observa Diná. Um plongée nos evidencia a posição dos sujeitos na cena e a centralidade do caixão, seguido por um corte para o rosto de Raul e o rápido movimento de Alexandre em direção ao irmão. Há um ágil jogo de câmeras: uma focaliza Alexandre de frente, plano médio, determinado a atacar Raul (figura 6); a outra representa os próprios olhos do personagem central, mostrando o que ele vislumbra no momento (figura 7); por fim, 0 plongée comprova a determinação do espírito ao caminhar em sentido a Raul, com as mãos inclinadas para atacar (figura 8). 
Alexandre transpassa o corpo do irmão quando tenta empurrá-lo e se mostra confuso com o que acontecera (figura 10). Em plano aberto e a partir de uma câmera parada (como se representasse a visão de Raul), vemos que Alexandre desfaz 0 movimento e distancia-se da câmera que o focaliza enquanto perpassa o próprio caixão (figura 11). Passamos novamente a enxergar pelos olhos do personagem principal, que olha para todos os presentes e detém-se ao caixão. Alexandre em plano médio, afastado, transfigura-se numa luz branca que desaparece do ambiente sob o mesmo efeito sonoro remetendo a sopro de vento já empregado quando surgira (figura 12).

0 emprego da câmera subjetiva permitiu figurar a visão conturbada do personagem e reforçou 0 teor didático empregado na telenovela: além das cores escuras para simbolizar a maldade, 0 estado de espírito perturbado, a obra se valeu da câmera subjetiva a fim de inserir 0 espectador na narrativa e dotar-lhe de reais condições para apreender ânsias e incertezas do espírito desencarnado. Alexandre surge no espaço como fumaça sem ser notado e, nesta mesma lógica, nós, espectadores, inserimo-nos na diegese através do olhar do personagem e compartilhamos de sua angústia.

Estas considerações demonstram o modo como o espiritismo foi dado a ver na década de 1990 na telenovela de Ivani Ribeiro. 0 excessivo uso das cores escuras para caracterizar Alexandre, a cela na qual se encontrava recluso, os sons perturbadores e angustiantes, os gritos dos presos, o choro dos presentes ao velório, os efeitos visuais para fazer surgir e desaparecer o espírito, este conjunto de elementos cênicos remonta a uma concepção maniqueísta típica das narrativas melodramáticas: a encarnação do mal em oposição ao bem. Alexandre encarna visualmente 0 estereótipo da maldade, do indivíduo que, por consequência das ações, segue atormentado para o plano espiritual.

Figuras 9-12: Alexandre circula pelo espaço sem ser notado em A Viagem
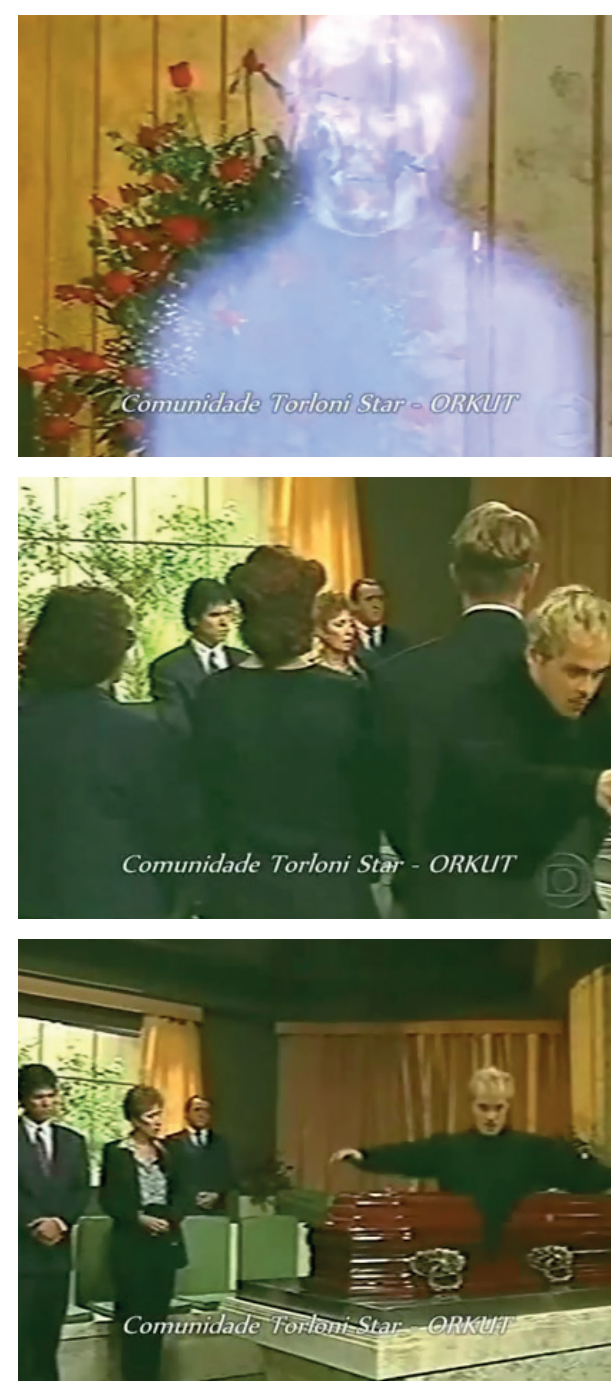


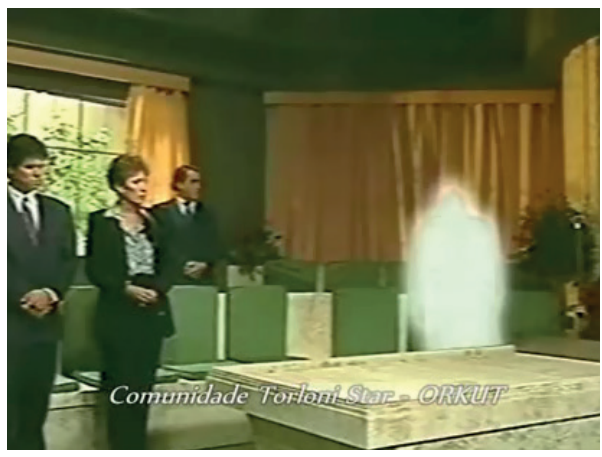

Fonte: Youtube

Tal didatismo para figurar a religiosidade espírita pode ser entendido como um esforço por popularizar de maneira clara a doutrina, na intenção de não incorrer em erros quanto a seus preceitos. A equipe da telenovela inspirouse nos livros Nosso Lar e $E$ a vida continua..., ambos psicografados por Chico Xavier, para compor a narrativa e evitar deslizes no enredo que pudessem prejudicar o desenrolar da trama. Na primeira versão da telenovela, exibida pela TV Tupi em 1975 e também escrita por Ivani Ribeiro, a autora recorrera a Herculano Pires - importante nome na divulgação espírita das décadas passadas - para adensar as pesquisas de roteiro.

Como se nota, na década de 1990, a obra manteve uma sustentação em pesquisas doutrinárias a fim de balizar o enredo. Além das obras de Chico Xavier citadas como suporte, é na referida década que os chamados "romances espíritas" adquiriram significativa visibilidade, principalmente atrelado a nomes como Vera Lúcia Marinzeck (psicografou Violetas da Janela, best-seller do segmento). Já em 1995, após o encerramento da novela, Brasília sediou o Congresso Espírita Mundial, tendo sido fundadas no mesmo ano a Associação MédicoEspírita do Brasil e a Associação Brasileira de Psicólogos Espíritas (HESSEN, 2013). Dessa maneira, o espiritismo começou a projetar-se e assumir novas feições tão $\log 0$ a telenovela se encerrou, como se $A$ Viagem concretizasse um primeiro passo para a difusão audiovisual da doutrina - que atingiria altos patamares na década seguinte.

\section{Alma Gêmea: novas figurações didáticas em cena}

Alma Gêmea, novela de Walcyr Carrasco exibida entre 2005 e 2006 no horário das 18 horas pela TV Globo, foi a telenovela de maior audiência da faixa na década passada, e seu último capítulo superou Belíssima (novela das 21 horas da época). Tamanho sucesso garantiu uma reprise da obra em 2009, repetindo a repercussã $0^{1}$.

0 primeiro evento narrativo traz a apresentação de balé clássico da personagem Luna que, agraciada pelo público e familiares, mostra-se efusiva com o sucesso alcançado. Ao sair do teatro, cercada por parentes e fotógrafos, Luna é vítima de um assalto e após o embate corporal entre Rafael (esposo de Luna) e 0 assaltante, ela se posta à frente do marido e é atingida por um disparo de arma de fogo (figura 13). A trilha simboliza 0 tom 
dramático da ocorrência e Luna cai nos braços do marido, sob os gritos dos presentes - como a mãe Agnes, com as mãos levadas ao rosto enquanto grita.

Figuras 13-15: A morte de Luna em Alma Gêmea
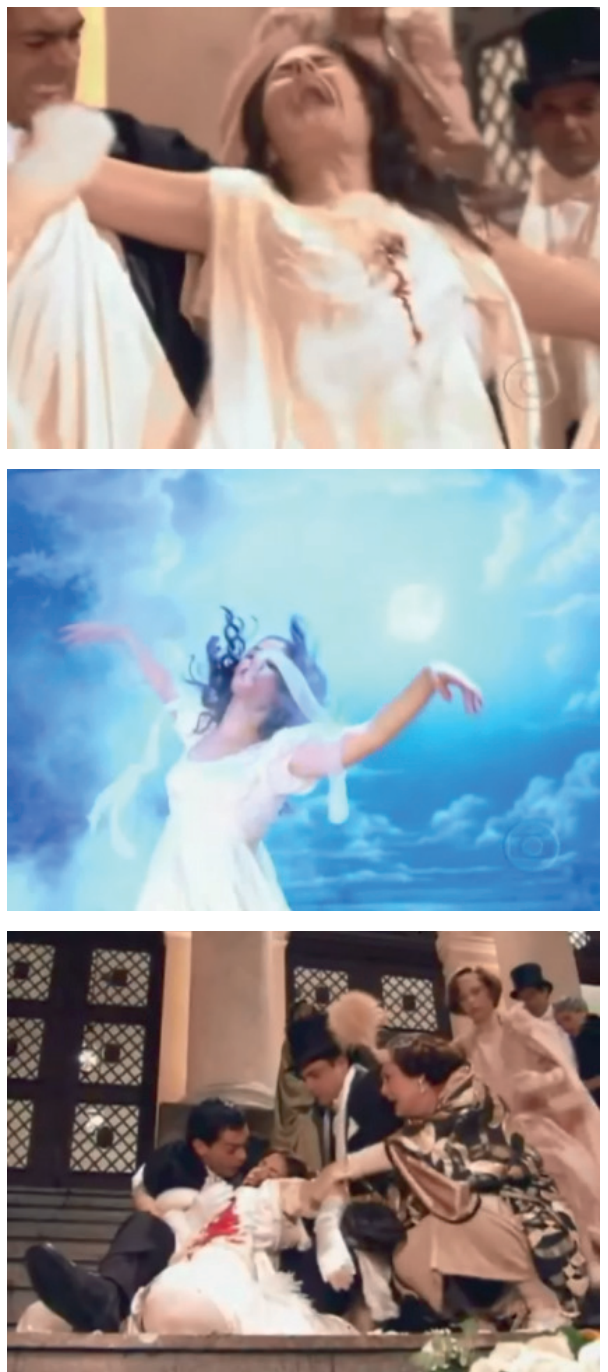

Fonte: Youtube

Corta-se para uma aparição da personagem se elevando ao céu (figura 14), entre nuvens azuis e tons claros advindos do sol. Luna, em espírito, rodopia sob o efeito de imagens de si própria em justaposição. Após instantes, seu espírito parece descer ao corpo e vemos a agonia da personagem. A trilha denota um clima funesto, enquanto as sequências de imagens prosseguem em câmera lenta. Avistam-se os bandidos fugindo. Um contra-plongée capta Luna, caída e ensanguentada, rodeada por pessoas (figura 15). A mãe grita desesperada; Rafael, em close up, sussurra palavras ao ouvido da esposa. A sequência se encerra com um grito de Rafael, olhando para o céu e pedindo socorro, enquanto a câmera se distancia de seu rosto e vai abrindo o quadro imagético, o que permite ver um grupo de pessoas em volta e as escadarias cheias de pétalas de rosas brancas próximas a Luna.

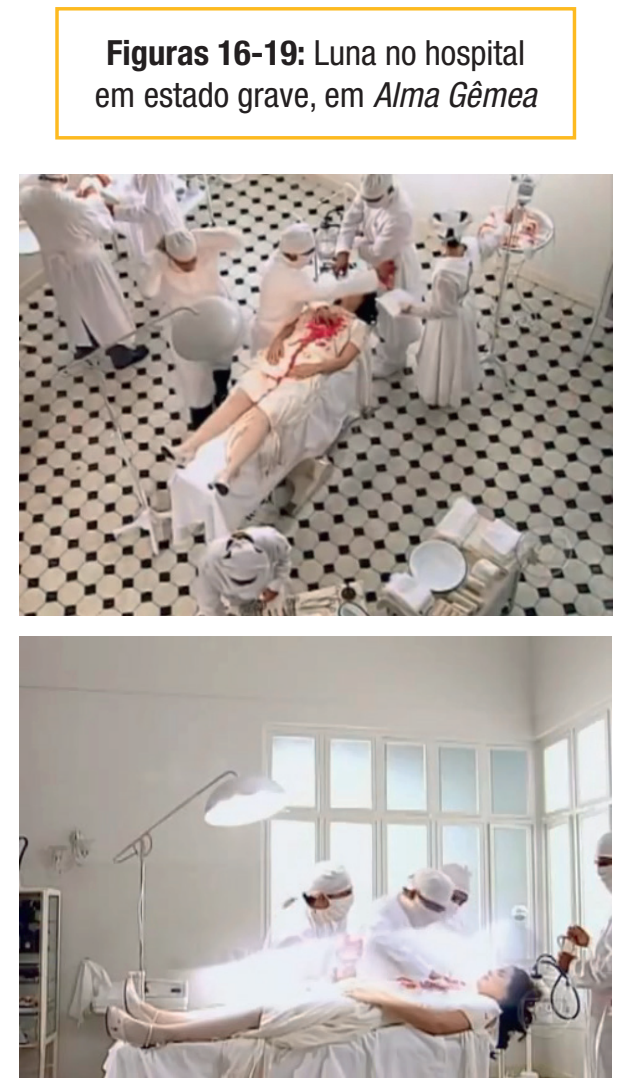



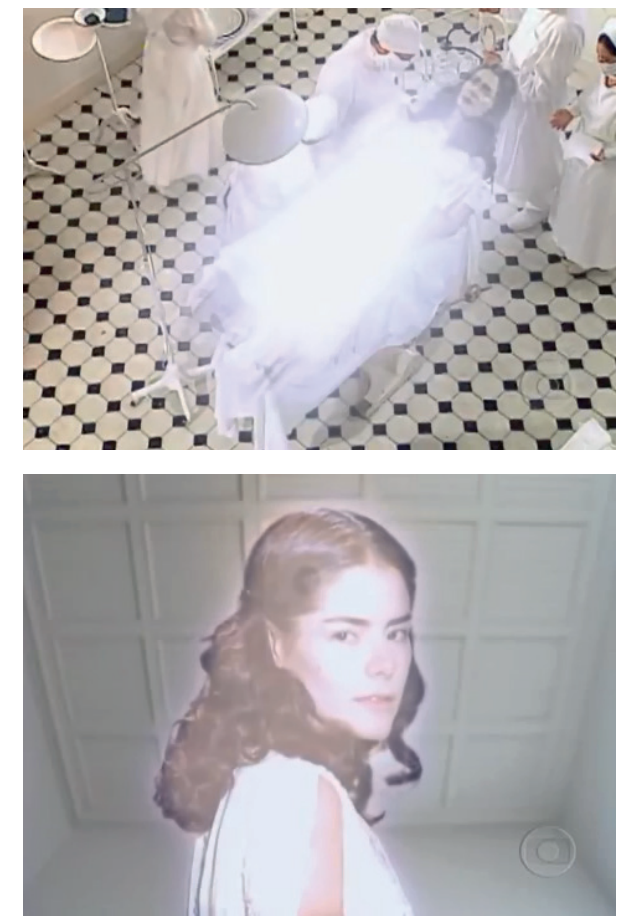

Fonte: Youtube

A próxima sequência apresenta Luna no

hospital, deitada à cama rodeada por médicos.

0 plongée nos revela 0 ambiente excessivamente branco (desde as roupas dos personagens até os equipamentos e paredes, exceto detalhes no piso). Luna ocupa o centro do quadro, inerte, e dela emana o principal elemento a destoar do branco ao redor - 0 vermelho do sangue que escorrera por seu vestido (figura 16).

Diante de uma ambientação suave, o sangue de Luna ao centro evoca a dor da personagem em seus momentos finais de vida, sinaliza para a brutalidade com que fora atingida e remete ao inevitável destino da moça: a morte. Como a sequência transcorre sob um plongée, tem-se a impressão de que a personagem é observada por uma instância superior que, do alto, aguarda 0 desfecho da ocorrência.
Em seguida, há um corte para um plano aberto que, ao nível dos presentes, acompanha as complicações no estado de Luna. A câmera se movimenta suavemente até se aproximar da lateral de Luna e exibir os esforços médicos para reanimá-la. A trilha é levemente tensa, $\log _{0}$ alterada para um efeito sonoro similar a sopro de vento, enquanto vemos o espírito de Luna se descolar do corpo a partir de um plano de conjunto capaz de figurar o desprendimento (figura 17). Voltamos ao plongée que evidencia a subida do espírito e seu distanciamento da matéria enquanto os humanos permanecem na vã tentativa de salvá-la (figura 18).

Rafael grita o nome de Luna e surge em plano de detalhe, logo sua imagem dá lugar à esposa, em contra-plongée, olhando para trás e vendo a movimentação ao redor de seu corpo (figura 19). Corta-se para plongée, com o espírito a ocupar toda a parte direita. 0 espírito de Luna sai do recinto e vemo-no flutuar à noite, acima das casas. Dentro do hospital, um plano de detalhe de Rafael se alterna a um plano de conjunto, o primeiro evidenciando o desespero do marido, ao passo que o segundo demonstra o pesar da equipe médica. 0 espírito da moça surge em plano médio: de um lado, uma forte luminosidade irradia sobre ela; de outro, o céu escuro, sendo ela a divisora cromática até que 0 clarão ocupa todo o fundo.

Rafael segue desesperado dentro do hospital, sobre 0 corpo da amada, enquanto o espírito 
de Luna flutua no céu claro, onde se projetam raios luminosos para os quais a personagem se dirige. Ao lado dela, o plano aberto permite captar imagens em tons suaves projetadas nas nuvens, rememorando passagens da existência terrena da mulher - como o casamento e o nascimento do filho. Rafael segue inconsolável, em plano médio agarrado à mão direita da esposa. Luna, espírito, sob trilha suave, sorri e aponta os dedos em direção frontal.

Posteriormente, vemo-na de costas, levitando em sentido a uma forte luz branca ao fim das nuvens. A luminosidade domina todo o quadro e, quase imperceptível, vê-se uma figura angelical, ao que parece denotar um ser superior de mãos estendidas para Luna. Os dedos dela, vistos num plano de detalhe, quase tocam 0 da divindade (figura 20), mas Rafael, enquadrado por contra-plongée, grita pela esposa. Neste instante, a trilha suave se desfaz, o espírito de Luna olha para trás e começa a se movimentar como se estivesse sob tormenta.
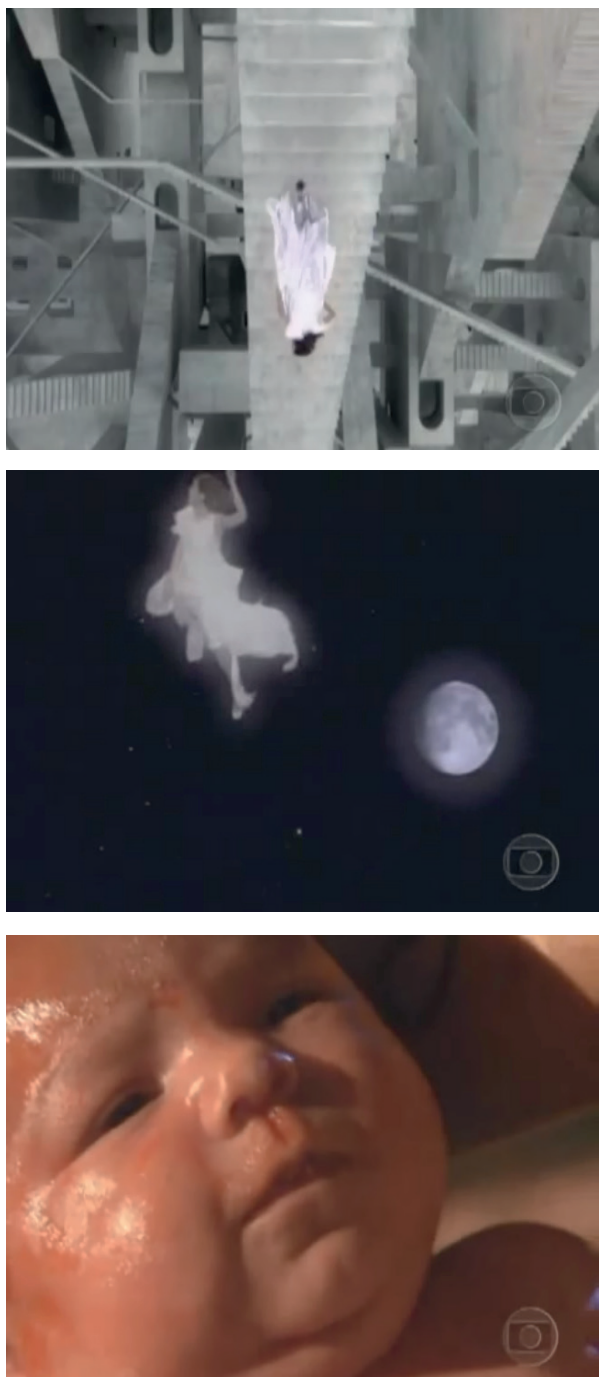

Fonte: Youtube
Figuras 20-23: Luna em espírito e reencarnando, em Alma Gêmea

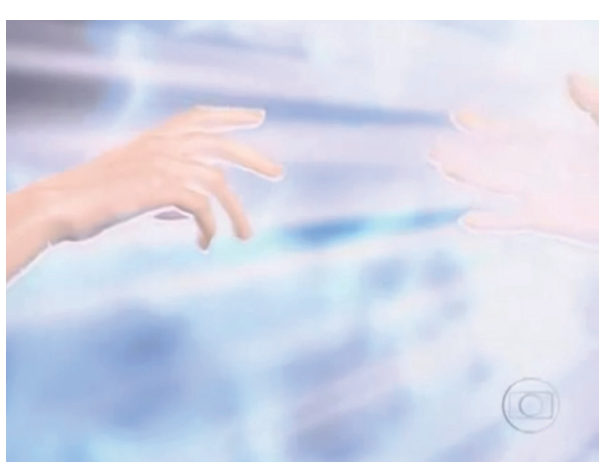

Luna está em plano aberto, captada de corpo inteiro enquanto as nuvens ficam escuras e passam ao lado dela. Luna não resiste e cai num labirinto com escadarias gigantescas. Ela é captada em contra-plongée e olha para cima, como se buscasse compreender de onde descera. Os planos seguintes são intensos: alguns abertos, mostram Luna descendo e subindo as escadarias, outros usam do plongée e contra-plongée para demonstrar 0 esforço dela para encontrar uma saída. Há inclusive imagens de Luna captadas 
de cabeça para baixo (figura 21), denotando a tormenta vivida pelo espírito naquele momento.

Ao fim, Luna chega ao topo das escadarias, captada em plano aberto, quando vemos seu impulso para pular e, ao fazê-lo, as escadarias começam a ruir enquanto cai. 0 s destroços desaparecem e, ao lugar deles, surge a noite, as estrelas e a lua. 0 plano aberto evidencia Luna e lua lado a lado (figura 22), brancas e em contraste ao céu escuro da noite, até que o espírito se transforma num ponto de luz que despenca do céu em direção à mata próxima de uma cachoeira. Ouvimos a queda d'água e há um travelling para a direita, revelando indígenas acompanhando um trabalho de parto. Sob gritos de "Força, Jaci", ecoa 0 choro da recém-nascida, embalado por trilha serena. Luna reencarnara (figura 23)!

As referências ao espiritismo em Alma Gêmea coadunam com a produção audiovisual da década em questão. 0 cinema nacional, a partir de 2008, viu emergir uma vertente de filmes espíritas que, ao contrário das telenovelas que dizem se inspirar na religião, assumia uma militância ao abordar a biografia de nomes consagrados da doutrina e adaptar livros famosos do espiritismo - como Bezerra de Menezes, o diário de um espirito (2008), Chico Xavier (2010), As cartas psicografas por Chico Xavier (2010) e Nosso Lar (2010). Além disso, foi nos anos 2000 que surgiram televisões espíritas, como Rede Visão (2004) e TV Mundo Maior (2006). 0 contexto audiovisual, portanto, sinalizava para a boa receptividade dos preceitos religiosos e cinema e TV conformavam uma experiência visual espírita de maior visibilidade.

Em termos estilísticos, o tom monocromático de Luna (cor branca) simboliza sua áurea de pureza: um espírito de elevação moral e, por isso, a composição cênica evoca a sutileza de seus traços (seu espírito esboça leves sorrisos, não expressa pesar em suas feições). Luna é a encarnação do bem, a materialização dos bons sentimentos que a levam à porta do céu. 0 melodrama, nesse caso, corrobora para a outra face do maniqueísmo já instaurado e detectado em A Viagem: na obra de Ivani Ribeiro, personificou-se o mal; em Alma Gêmea, figurou-se estilisticamente 0 bem.

Em termos estruturais, o melodrama é uma composição muito simples. Bipolar, estabelece contrastes em nível horizontal e vertical. Horizontalmente, opõe personagens representativas de valores opostos: vício e virtude. No plano vertical, altera momentos de extrema desolação e desespero, com outros de serenidade ou de euforia (HUPPES, 2000, p. 27)

No universo constituinte do melodrama, há somente "duas alternativas rotuladas desde o começo, uma corresponde ao bem; a outra, ao mal. 0 conflito é claramente um embate entre campos separados e as personagens - como os espectadores - têm suficiente lucidez para distinguir um do outro" (HUPPES, 2000, p. 111-112). Além do didatismo visual mantido em Alma Gêmea, o maniqueísmo não fora abandonado, mesmo num cenário audiovisual de eminentes produções ficcionais claramente 
sustentadas nos preceitos da religião espírita. Com esta maior projeção da doutrina, Alma Gêmea não só se valeu do maniqueísmo e didatismo, mas foi a única das produções consideradas a figurar a morte, o descolamento do espírito e a reencarnação. 0 sucesso de Alma Gêmea produziu resultados imediatos na TV Globo. Ainda em 2006, a emissora levou ao ar o remake de $O$ Profeta, também obtendo bons índices de audiência que lhe garantiram uma reprise em 2013. Estava instaurado um novo ciclo de produções que culminariam num dos mais recentes sucessos da faixa das 18 horas: Além do Tempo.

\section{Além do Tempo e a figuração religiosa em narrativas complexas}

Além do Tempo foi exibida de julho de 2015 a janeiro de 2016 na faixa das 18 horas da TV Globo. Escrita por Elizabeth Jhin, a telenovela foi amplamente apreciada pela crítica televisiva ao sustentar-se num novo formato (com a passagem de tempo de 150 anos $)^{2}$. A audiência da trama atingia aos propósitos da faixa e a boa repercussão da obra foi mantida do início ao fim.

Coletamos a sequência da morte de Lívia e Felipe, centrais na trama de Jhin. Eles estão no alto de um penhasco, juntos, felizes por estarem lado a lado após inúmeras interferências de Pedro e Melissa - os vilões. Porém, Pedro aparece, ataca Felipe e pretende matá-lo. Enquanto lutam,
Melissa também surge e empurra Lívia penhasco abaixo. Felipe logo corre para tentar salvá-la e também fica pendurado, segurando-a com uma das mãos e se apoiando à beira do penhasco na tentativa de conter a queda. Ao ver a atitude de Melissa, Pedro mata a jovem e, de pé, olha para o casal em apuros. Lívia implora por ajuda, mas Pedro ataca Felipe e este perde as forças.
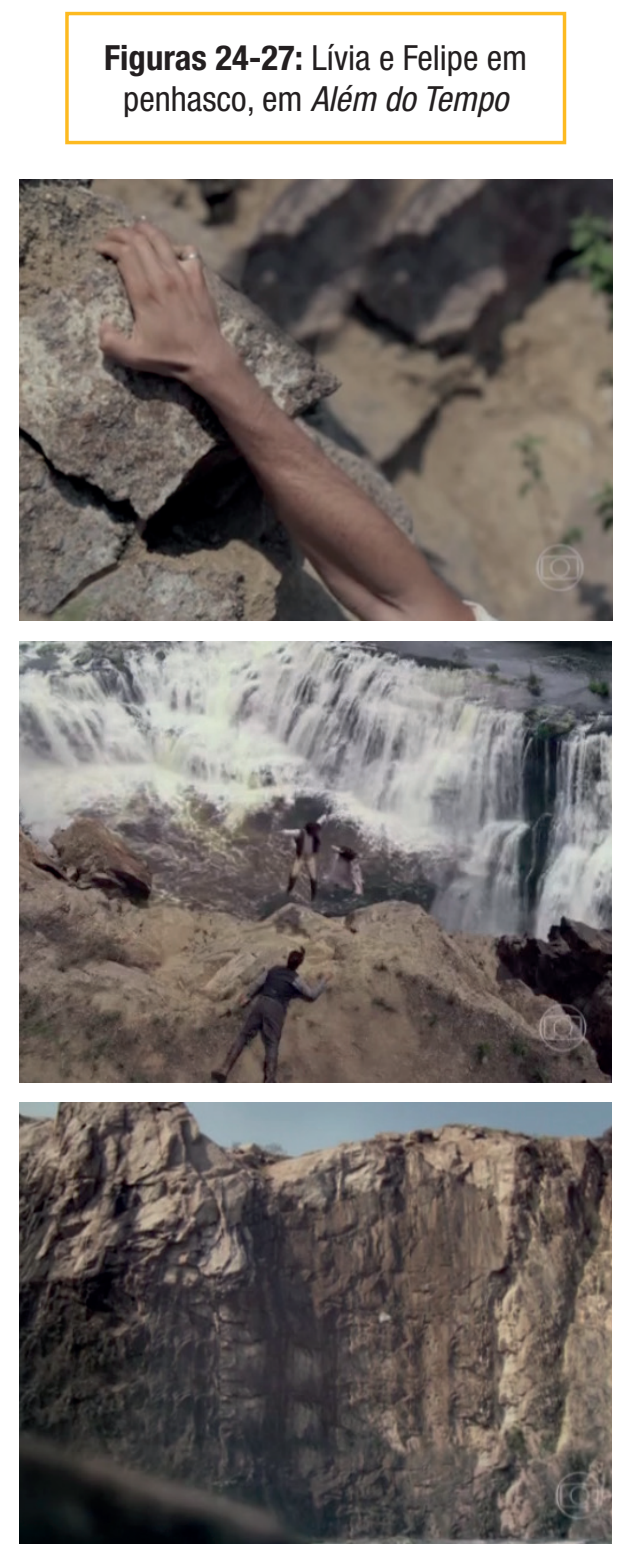


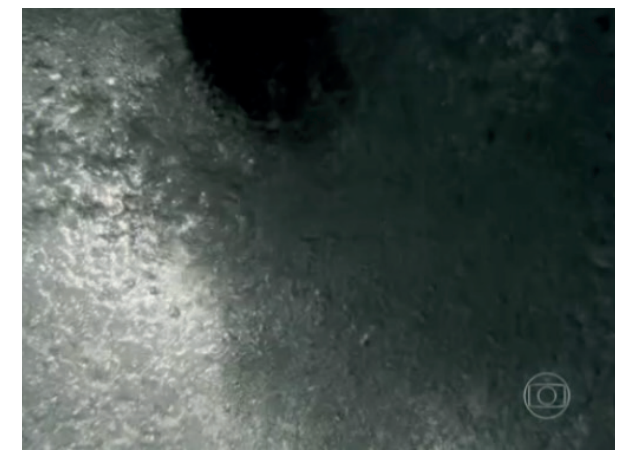

Fonte: Globoplay

Um jogo de plongée e contra-plongée apresenta o posicionamento dos sujeitos: para captar Pedro, que está acima, no controle da situação e 0 único que poderia salvar o casal, usa-se 0 contra-plongée; quando mostrados, Lívia e Felipe são vistos por meio de plongée, inferiorizados no contexto narrativo, pois não são mais capazes de controlar a si próprios. A trilha dá o tom de instabilidade da sequência. Ao fundo do casal, vêse desfocada a grande cachoeira com suntuosas quedas d'água. Pedro apunhala Felipe e este perde as forças. A trilha musical se interrompe, há ruído da espada quando perfura o corpo de Felipe e logo quando é retirada por Pedro. Um close na mão de Felipe, desprendendo os dedos (figura 24) e voltamos a ver os personagens através do contraplongée enquanto caem. Em seguida, um plano aberto, plongée, ambienta-nos quanto ao tamanho da tragédia: Pedro, deitado no alto do penhasco, assiste à queda do casal na imensidão de águas (figura 25). 0s humanos estão diminutos, são pequenos e imperceptíveis quando captados em plano geral que traz o paredão rochoso a figurar a imensidão da natureza e da tragédia ali ocorrida ao casal (figura 26).
Figuras 28-31: Lívia e Felipe abraçados, afogando-se, mortos
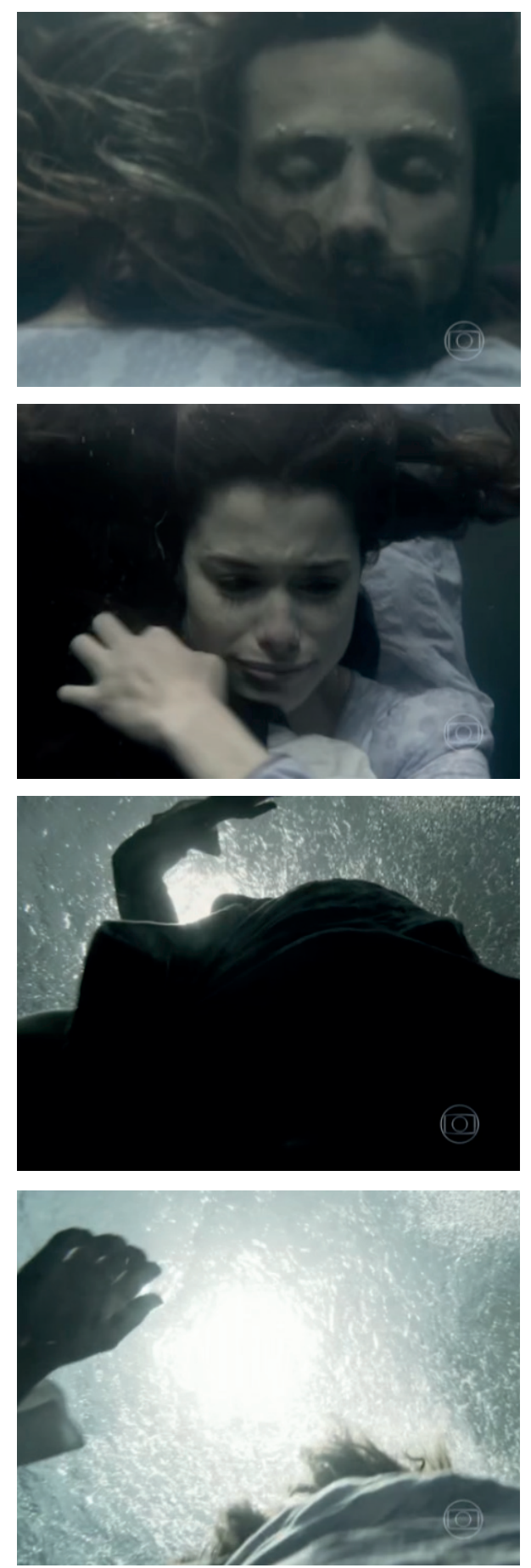

Fonte: Globoplay 
0 silêncio é quebrado com o impacto e a agitação das águas quando ambos caem, vistos em contraplongée. A câmera está no fundo do lago, todo o quadro é tomado por água e, por entre borbulhas, nota-se 0 clarão do sol. Felipe e Lívia estão abraçados, em primeiro plano; vemos o rosto de Felipe e as águas já estão calmas (figura 28). Em seguida, todo oframe escuro é posposto por uma tomada com o rosto de Lívia (figura 29), em primeiro plano, acariciando os cabelos de Felipe. Volta-se ao enquadramento frontal de Felipe e a câmera balança enquanto se aproxima dele, acompanhando 0 agitar das águas. Após frame escuro, novamente Lívia está no centro da imagem abrindo os olhos e abraçando o rapaz. 0 plano médio seguinte os enquadra lateralmente e um zoom in nos leva próximo ao rosto de Felipe. 0 contra-plongée encerra a agonia do afogamento, sinalizando para a queda dos corpos ao fundo do lago e, à medida que afundam, dão a ver o clarão do sol sobre as águas (figuras 30-31).

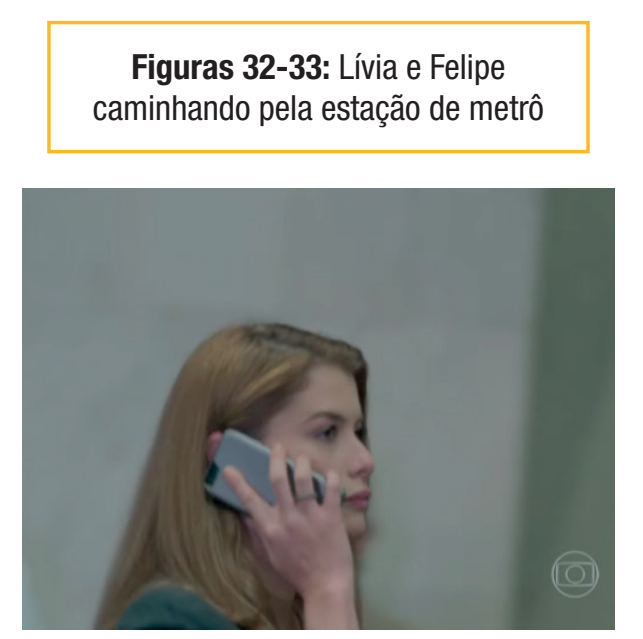

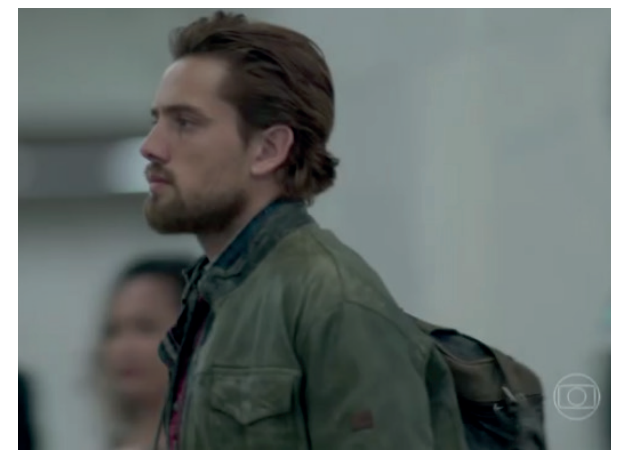

Fonte: Globoplay

0 clarão dá lugar a um metrô em alta velocidade, que se intercala à imagem de Lívia, em plano médio, caminhando por entre a multidão à espera do transporte, e à imagem de Felipe, caminhando pela estação (figura 33). As câmeras que os focalizam por travelling sugerem a velocidade dos novos tempos (Lívia anda apressada enquanto fala ao celular - figura 32) e demarcam a temporalidade e ambiência da nova fase. Há uma intensa justaposição de frames de Lívia e Felipe, demonstrando o caminhar de ambos em sentidos opostos, até que param diante de portas do metrô: Lívia adentra, mas Felipe é impedido por um sujeito. Há um close em Lívia, atônita ao ver Felipe do lado de fora (porém, sem saber o que, de fato, os unia). Há um close em Felipe, captado de dentro do vagão, pois ele é visto através da porta do metrô. A porta se fechou, ele não conseguiu entrar, ficaram apenas se entreolhando. Final do capítulo!

Além do Tempo reelabora o esquema de figuração da morte e da reencarnação, distanciando-se estilisticamente das outras duas produções. A ausência de espíritos ou um plano transcendental e a subsequente passagem de tempo sinalizam 
para um amadurecimento nos modos de debater o espiritismo nas telenovelas. Levando em conta o cenário recente de narrativas complexas, muito exploradas em seriados americanos e já pinceladas em produções nacionais ${ }^{3}$, a telenovela não recorreu ao didatismo para figurar a religiosidade e a transição de séculos. 0 espectador, convocado a participar da narrativa, subentende 0 avanço cronológico graças a elementos diegéticos, tais como a mudança de figurinos, a alteração nos locais onde se encontram (estavam num rochedo, depois aparecem numa estação de metrô), os aparatos e os modos de sociabilidade implicados (antes, portavam espadas, agora seguram celulares). Em termos estilísticos, não há a exploração do maniqueísmo e do didatismo outrora empregado na TV.

Considerando a evolução das produções citadas, tem-se um evidente contexto de experiências visuais orientando a percepção coletiva acerca dos fundamentos básicos do espiritismo. Ao chegarmos aos dias atuais, a telenovela parece não necessitar de procedimentos didáticos para discutir uma problemática tão intensa como é a morte e a reencarnação. A televisualidade nos permitiu identificar estas alterações e captar o enredo de Jhin como uma produção ousada. Em termos de consumo, de alguma maneira as audiências já apreendem a temática com outro olhar se comparado aos parâmetros que norteavam as produções de $A$ Viagem e Alma Gêmea.
Logo após o encerramento de Alma Gêmea, seguiram-se produções ficcionais assentadas no filão espiritualista. Além de 0 Profeta, já citada, outras tramas alicerçaram suas histórias em preceitos espíritas, como questões espirituais atreladas a avanços científicos (Escrito nas Estrelas, 2010), crença em vidas passadas e regressão (Amor, eterno amor, 2012), ou tons de humor ao abordar sensitivos, influências espirituais e comunicação entre mundo material e mundo espiritual (Alto Astral, 2014). A própria autora de Além do Tempo é a responsável por consagrar produções de teor espiritualista que, apesar das negativas de Jhin, vêm sendo chamados de "telenovelas espíritas". Dessa maneira, o grande número de produções ficcionais já inspiradas no espiritismo parece ter construído os pilares culturais para que a mais recente obra (Além do Tempo) inovasse ao figurar a reencarnação, a pluralidade de existências e a influência dos espíritos.

\section{Considerações finais}

A figuração de preceitos espíritas nas telenovelas sofreu ressignificações ao longo das décadas. Enquanto A Viagem e Alma Gêmea exploraram uma conformação televisual didática, quase manuais de orientação doutrinária, Além do Tempo caminhou numa construção televisual que abandona tais modos de figurar morte 
e reencarnação. A morte, nas três obras, é sempre um acontecimento trágico, envolto por assalto, suicídio ou afogamento. A morte é 0 sofrer. 0 renascer ou ver-se na condição de espírito, em tese, seria a alternativa para as ações e deslizes cometidos em vida. Apesar de se distanciarem em alguns preceitos, todas as telenovelas permanecem evidenciando marcas genéricas do melodrama, como a condição de vítimas dos personagens principais, numa clara referência aos estereótipos clássicos do melodrama: Alexandre é vítima de si próprio, de seu descontrole; Luna é vítima de um assalto (forjado pela prima); Lívia e Felipe são vitimas do ódio de Melissa e Pedro.

Com relação aos elementos estilísticos empregados, os cenários e a cenografia, figurinos, efeitos visuais, movimentos de câmera e enquadramentos foram fundamentais para construir a narrativa visual das mortes e reaparição dos personagens principais nas telenovelas. No caso das duas primeiras, serviram a uma função didática; já na obra de Jhin, evidenciaram um amadurecimento para tratar da reencarnação e da imortalidade da alma.

Em sociedades marcadamente assentadas na alfabetização audiovisual como a nossa, seria possível escapar do didatismo ou do maniqueísmo na hora de figurar preceitos religiosos? Além do Tempo nos dá pistas quanto a este quesito. Não se trata de mera evolução técnica que permitiu a visualidade de preceitos espíritas de modo inovador. Se a mais recente narrativa melodramática a abordar esta temática valeu-se de um esquema distinto do que se adotara em décadas precedentes, podemos ponderar que fatores de ordem cultural foram determinantes nesta guinada e, portanto, permitiram que se abandonassem maniqueísmos e didatismos ao tratar do assunto. Dito de outro modo, significa reconhecer o potencial das alterações sociais neste processo.

Gostaríamos de esclarecer que os críticos e sites especializados em TV, quando citam as referidas obras, exaltam o lado "espírita" das mesmas, como se essa fosse a principal característica definidora destes melodramas. Não faltam listas produzidas por comentaristas de TV elencando as "telenovelas espíritas" já exibidas no país ${ }^{4}$. Por outro lado, os autores das obras preferem se distanciar desta rotulação e alegam produzir conteúdos de mera inspiração na temática espiritualista, sem que isto signifique adaptação de uma religiosidade específica. Diante deste impasse, obviamente não temos condições de sinalizar para a emergência

Alguns exemplos destas considerações podem ser vistas em textos elencados a seguir, acessados em 7 de dezembro de 2017: a) http://www.purepeople.com.br/noticia/relembre-novelas-com-tema-espirita-como-alto-astral-que-estreia-nestasegunda_a29697/1

b) http://vejasp.abril.com.br/blogs/listamania/2015/06/17/globo-novela-espiritismo/

c) http://rd1.ig.com.br/relembre-novelas-da-globo-que-ja-abordaram-0-espiritismo/ 
de um subgênero melodramático, mas estamos diante de uma problematização ligada a tais produtos que certamente demandará reflexões e debates para entendermos as fissuras deste processo, evidenciadas pela televisualidade quando se trata de morte e toda a mística que a cerca - principalmente em nosso contexto latino de profundas crenças religiosas.

\section{Referências}

ARRIBAS, C. G. Afinal, espiritismo é religião? São Paulo: Alameda Editorial, 2010.

AUBRÉE, Marion; LAPLANTINE, François. A mesa, o livro e os espíritos: gênese, evolução e atualidade do movimento social espírita entre a França e o Brasil. Maceió: EdUFAL, 2009.

BORDWELL, David. Figuras traçadas na luz: a encenação no cinema. Trad. Maria Luiza Machado Jatobá. Campinas: Papirus, 2008.

BREA, José Luis.Los estudios visuales: por una epistemología política de la visualidad. Centro de Estudios Visuales de Chile, Señas y Reseñas, 2009. (tradução nossa).

BUTLER, Jeremy. Television Style. New York: Routledge, 2010. (tradução nossa).

DAMAZI0, Sylvia F. Da elite ao povo: advento e expansão do espiritismo no Rio de Janeiro. Rio de Janeiro: Bertrand Brasil, 1994.

GIUMBELLI, Emerson. 0 cuidado dos mortos: uma história da condenação e legitimação do espiritismo. Rio de Janeiro: Arquivo Nacional, 1997.

HUPPES, Ivete. Melodrama: 0 gênero e sua permanência. Cotia: Ateliê Editorial, 2000.

HESSEN, Jorge. História do espiritismo no Brasil. Jornal 0 Debate. Disponível em http://orebate- jorgehessen.blogspot.com.br/2013/08/historia-doespiritismo-no-brasil.html. Acessado em 12 de Nov 2016.

KARDEC, Allan. 0 espiritismo em sua expressão mais simples. Rio de Janeiro: FEB, 2007a. o que é o espiritismo. $70^{\mathrm{a}}$ ed. Araras: IDE, $2007 \mathrm{~b}$.

LEWGOY, B. Os espíritas e as letras: um estudo antropológico sobre cultura escrita e oralidade no espiritismo kardecista. Tese (Doutorado) Universidade de São Paulo, São Paulo, 2000.

LOPES, Maria Immacolata Vassalo de.

(org)Telenovela:Internacionalização e interculturalidadeSão Paulo: Edições Loyola, 2004. MACHAD0, Ubiratan.0s intelectuais e o espiritismo. Niterói: Lachâtre, 1996.

MARTIN-BARBER0, Jesús; REY, Germán. 0s exercícios do ver: hegemonia audiovisual e ficção televisiva. Trad. Jacob Gorender. São Paulo: Editora Senac São Paulo, 2001.

\section{MITCHELL, W. J. T. What do pictures "really"} want?Chicago: The University of Chicago Press, 2005. (tradução nossa).

. Teoría de la imagen: ensayos sobre representación verbal y visual. Trad. Yaiza Hernández Velázquez. Madri: Ediciones Akal, 2009. (tradução nossa).

\section{MITTELL, Jason. Television and American}

Culture.New York: Oxford University Press, 2010. (tradução nossa).

PAVAM, Daniel. As fronteiras identitárias do espiritismo em Juiz de Fora. Dissertação (Mestrado em Ciência da Religião) - Universidade Federal de Juiz de Fora, Juiz de Fora, 2003.

PEGORARO, Éverly. Estudos Visuais: principais autores e questionamentos de um campo emergente. Revista Domínios da Imagem, Londrina, ano IV, $\mathrm{n}^{\circ} 8, \mathrm{p}$. 41-52, maio 2011. 
ROCHA et al. 0 estilo televisivo e sua pertinência para a TV como prática cultural. Florianópolis: Insular, 2016.

ROCHA, Simone M. ALVES, Matheus L. C. 0 realismo maravilhoso: uma matriz estético-cultural latinoamericana e sua manifestação no estilo da telenovela brasileira. Seminário - Ficção, Mídia e Política: processos e intersecções. Faculdade Cásper Líbero, São Paulo, 17 de maio de 2014.

ROCHA, Simone M.; ALVES, Matheus Luiz Couto; OLIVEIRA, Lívia Fernandes de. A História através do estilo televisivo: a Revolta da Vacina na telenovela Lado a Lado. Revista Eco-Pós(Online), v 16, 2013.

ROCHA, Simone M. 0 estilo televisivo e sua pertinência para a TV como prática cultural. Revista Famecos, v 21, n 03, 2014.

SANTOS, José Luiz dos. Espiritismo: uma religião brasileira. São Paulo: Moderna, 1997.

STOLL, Sandra J. Entre dois mundos: 0 espiritismo na França e no Brasil. Tese (Doutorado em Antropologia) - Faculdade de Filosofia, Letras e Ciências Humanas, Universidade de São Paulo, São Paulo, 1999.

\section{Telenovelas}

ALÉM DO TEMPO. Novela de Elizabeth Jhin. Escrita por Elizabeth Jhin, com colaboração de Eliane Garcia, Lílian Garcia, Duba Elia, Vinícius Vianna, Wagner de Assis e Renata Jhin. Direção geral: Pedro Vasconcelos. Elenco: Aline Moraes, Rafael Cardoso, Paolla Oliveira, Ireve Ravache, e outros. Rio de Janeiro, 18h, 13 de julho de 2015 a 15 de janeiro de 2016, 161 capítulos.

ALMA GÊMEA. Novela de Walcyr Carrasco. Escrita por Walcyr Carrasco, com colaboração de Thelma Guedes. Direção geral: Jorge Fernando. Elenco: Eduardo Moscovis, Priscila Fantin, Flávia Alessandra, Elizabeth Savalla, Ana Lúcia Torre e outros. Rio de Janeiro, 18h, de 20 de junho de 2005 a 10 de março de 2006, 227 capítulos.
A VIAGEM. Novela de Ivani Ribeiro. Escrita por Ivani Ribeiro, com colaboração de Solange Castro Neves. Direção geral: Wolf Maya. Elenco: Cristiane Torloni, Antônio Fagundes, Maurício Mattar, Lucinha Lins, Laura Cardoso e outros. Rio de Janeiro, 19h, 11 de abril a 21 de outubro de 1994, 167 capítulos. 


\section{The religion through style: the figuration of spiritism in the brazilian's telenovelas}

\section{Abstract}

We analyze the figuration of spiritism in three TV Globo telenovelas: A Viagem, Alma Gêmea and Além do Tempo, paying attention to the narrative events in which the plot's main characters die. The focus on this narrative retreat makes us able to grasp stylistic alterations in the figuration modes of some religious precepts, like existence of the soul, reincarnation and spirits' effects on terrestrial materiality. We notice a stronger didactic content in the first two telenovelas, not reinforced in the last. Supported by Visual Studies and Jeremy Butler's methodology about television style, we seek to point out stylistic advances associated to sociocultural reconfigurations (televisuality).

\section{Keywords}

Televisuality. Narrative event. Spiritism.

\section{La religión a través del estilo: la figuración del espiritismo en las telenovelas brasileñas}

\section{Resumen}

Analizamos la figuración del espiritismo en tres novelas de TV Globo: A Viagem, Alma Gêmea y Além do Tempo, centrando en eventos narrativos en los cuales ocurre la muerte de personajes principales. Esa trayectoria histórica permite captar alteraciones estilísticas en el modo de figurar preceptos básicos de la religión, como la existencia de alma, reencarnación y actuación de los espíritus sobre la materialidad terrestre. Se nota mayor tenor didáctico en las dos primeras obras, no reforzado en la última. Sustentados por los Estudios Visuales y la metodología de Jeremy Butler sobre estilo televisivo, apuntamos avances estilísticos asociados a reconfiguraciones socioculturales (televisualidad).

\section{Palabras clave}

Televisualidad. Evento narrativo. Espiritismo. 


\section{Expediente}

A revista E-Compós é a publicação científica em formato eletrônico da Associação Nacional dos Programas de Pós-Graduação em Comunicação (Compós). Lançada em 2004, tem como principal finalidade difundir a produção acadêmica de pesquisadores da área de Comunicação, inseridos em instituições do Brasil e do exterior.

\section{E-COMPÓS I www.e-compos.org.br I E-ISSN 1808-2599}

Revista da Associação Nacional dos Programas de Pós-Graduação em Comunicação. Brasília, v.20, n.3, set./dez. 2017. A identificação das edições, a partir de 2008 , passa a ser volume anual com três números. Indexada por Latindex I www.latindex.unam.mx

\section{CONSELHO EDITORIAL}

Ada Cristina Machado Silveira, Universidade Federal de Santa Maria, Brasil Alda Cristina Silva da Costa, Universidade Federal do Pará, Brasil Alfredo Luiz Paes de Oliveira Suppia, Universidade Estadual de Campinas, Brasil Ana Regina Barros Rego Leal, Universidade Federal do Piauí, Brasil Ana Carolina Rocha Pessôa Temer, Universidade Federal de Goiás, Brasil André Luiz Martins Lemos, Universidade Federal da Bahia, Brasil Angela Cristina Salgueiro Marques, Universidade Federal de Minas Gerais, Brasil Ângela Freire Prysthon, Universidade Federal de Pernambuco, Brasil Antonio Carlos Hohlfeldt, Pontifícia Universidade Católica do Rio Grande do Sul, Brasil Arthur Ituassu, Pontifícia Universidade Católica do Rio de Janeiro, Brasil

Bruno Campanella, Universidade Federal Fluminense, Brasil

Cláudio Novaes Pinto Coelho, Faculdade Cásper Líbero, Brasil Cárlida Emerim, Universidade Federal de Santa Catarina, Brasil Carlos Eduardo Franciscato, Universidade Federal de Sergipe, Brasil Danilo Rothberg, Universidade Estadual Paulista, Brasil Denise Tavares da Silva, Universidade Federal Fluminense, Brasil Diógenes Lycarião, Universidade Federal do Ceará, Brasil Eduardo Vicente, Universidade de São Paulo, Brasil Eliza Bachega Casadei, Escola Superior de Propaganda e Marketing - SP, Brasil Eneus Trindade, Universidade de São Paulo, Brasil

Erick Felinto de Oliveira, Universidade do Estado do Rio de Janeiro, Brasil Erly Vieira Júnior, Universidade Federal do Espírito Santo, Brasil Francisco de Assis, FIAM-FAAM Centro Universitário, Brasi

Francisco Elinaldo Teixeira, Universidade Estadual de Campinas, Brasil Francisco Gilson R. Pôrto Jr., Universidade Federal do Tocantins, Brasil Frederico de Mello Brandão Tavares, Universidade Federal de Ouro Preto, Brasil Gabriela Reinaldo, Universidade Federal do Ceará, Brasil Gilson Vieira Monteiro, Universidade Federal do Amazonas, Brasil Gustavo Daudt Fischer, Universidade do Vale do Rio dos Sinos, Brasil Itania Maria Mota Gomes, Universidade Federal da Bahia, Brasil Jiani Adriana Bonin, Universidade do Vale do Rio dos Sinos, Brasil José Afonso da Silva Junior, Universidade Federal de Pernambuco, Brasil José Luiz Aidar Prado, Pontifícia Universidade Católica de São Paulo, Brasi Josette Maria Monzani, Universidade Federal de São Carlos, Brasi Juçara Gorski Brittes, Universidade Federal de Ouro Preto, Brasil
Juliana Freire Gutmann, Universidade Federal da Bahia, Brasil Laura Loguercio Cánepa, Universidade Anhembi Morumbi, Brasil Leonel Azevedo de Aguiar, Pontifícia Universidade Católica do Rio de Janeiro, Brasil Letícia Cantarela Matheus, Universidade do Estado do Rio de Janeiro, Brasil Luciana Coutinho Souza, Universidade de Sorocaba, Brasil Maria Ataide Malcher, Universidade Federal do Pará, Brasil Maria Elisabete Antonioli, Escola Superior de Propaganda e Marketing - SP, Brasil Maria das Graças Pinto Coelho, Universidade Federal do Rio Grande do Norte, Brasil Marialva Carlos Barbosa, Universidade Federal do Rio de Janeiro, Brasil Marcel Vieira Barreto Silva, Universidade Federal da Paraíba, Brasil Marcia Tondato, Escola Superior de Propaganda e Marketing, Brasil Marli Santos, Universidade Metodista de São Paulo, Brasil

Márcio Souza Gonçalves, Universidade do Estado do Rio de Janeiro, Brasil Mauricio Mario Monteiro, Universidade Anhembi Morumbi, Brasil Mayka Castellano, Universidade Federal Fluminense, Brasil

Mozahir Salomão Bruck, Pontifícia Universidade Católica de Minas Gerais, Brasil Nisia Martins Rosario, Universidade Federal do Rio Grande do Sul, Brasil Paolo Demuru, Universidade Paulista, Brasil

Paula Melani Rocha, Universidade Estadual de Ponta Grossa, Brasil Potiguara Mendes Silveira Jr, Universidade Federal de Juiz de Fora, Brasil Priscila Ferreira Perazzo, Universidade Municipal de São Caetano do Sul, Brasil Rafael Cardoso Sampaio, Universidade Federal do Paraná, Brasil Rafael Tassi Teixeira, Universidade Tuiuti do Paraná, Brasil Regiane Lucas Garcês, Universidade Federal de Minas Gerais, Brasil Regiane Regina Ribeiro, Universidade Federal do Paraná, Brasil Renata Pitombo Cidreira, Universidade Federal do Recôncavo da Bahia, Brasil Renato Essenfelder, Escola Superior de Propaganda e Marketing, Brasil Roberto Elísio dos Santos, Universidade Municipal de São Caetano do Sul, Brasil Rodolfo Rorato Londero, Universidade Estadual de Londrina, Brasil Roseli Figaro, Universidade de São Paulo, Brasil

Simone Maria Andrade Pereira de Sá, Universidade Federal Fluminense, Brasil Sofia Cavalcanti Zanforlin, Universidade Católica de Brasília, Brasil Sônia Caldas Pessoa, Universidade Federal de Minas Gerais, Brasil Tatiana Oliveira Siciliano, Pontifícia Universidade Católica do Rio de Janeiro, Brasil Thaïs de Mendonça Jorge, Universidade de Brasília, Brasil

Valquiria Michela John, Universidade Federal do Paraná, Brasil

\section{CONSELHO CIENTÍFICO}

Cristiane Freitas Gutfreind, Pontifícia Universidade Católica do Rio Grande do Sul, Brasil | Eduardo Antônio de Jesus, Universidade Federal de Minhas Gerais, Brasil I Eduardo Morettin, Universidade de São Paulo, Brasil I Irene de Araújo Machado, Universidade de São Paulo, Brasil I Miriam de Souza Rossini, Universidade Federal do Rio Grande do Sul, Brasil

\section{COMISSÃO EDITORIAL}

Eduardo Antonio de Jesus, Universidade Federal de Minas Gerais, Brasil I Igor Pinto Sacramento, Universidade Federal do Rio de Janeiro, Brasil I Kelly Cristina de Souza Prudencio, Universidade Federal do Paraná, Brasil I Osmar Gonçalves dos Reis Filho, Universidade Federal do Ceará, Brasil I Rafael Grohmann, FIAMFAAM - Centro Universitário, Brasil (editor associado)

\section{CONSULTORES AD HOC}

Afonso de Albuquerque, Universidade Federal Fluminense, Brasil I Francisco Rüdiger, Pontifícia Universidade Católica do Rio Grande do Sul, Brasil I Gislene da Silva, Universidade Federal de Santa Cataria, Brasil I Luiz Cláudio Martino Universidade de Brasília, Brasil I Magali Nascimento Cunha, Universidade Metodista de São Paulo, Brasil I Márcia Franz Amaral, Universidade Federal de Santa Maria, Brasil I Tania Marcia Cezar Hoff, Escola Superior de Propaganda e Marketing, Brasil I Raquel Paiva, Universidade Federal do Rio de Janeiro, Brasil

\section{EQUIPE TÉCNICA}

ASSISTENTE EDITORIAL Márcio Zanetti Negrini I REVISÃO DE TEXTOS Melina Santos I EDITORAÇÃO ELETRÔNICA Roka Estúdio
COMPÓS I www.compos.org.br

Associação Nacional dos Programas de Pós-Graduação em Comunicação

Presidente

Marco Roxo

Programa de Pós-Graduação em Comunicação - UFF marcos-roxo@uol.com.br

Vice-Presidente

Isaltina Gomes

Programa de Pós-Graduação em Comunicação - UFPE isaltina@gmail.com

Secretária-Geral

Gisela Castro

Programa de Pós-Graduação em Comunicação

e Práticas de Consumo - ESPM

castro.gisela@gmail.com

CONTATO I revistaecompos@gmail.com 